\title{
Protease from Aspergillus oryzae: Biochemical Characterization and Application as a Potential Biocatalyst for Production of Protein Hydrolysates with Antioxidant Activities
}

\author{
Ruann Janser Soares de Castro and Helia Harumi Sato \\ Department of Food Science, School of Food Engineering, University of Campinas, 80 Rua Monteiro Lobato, \\ 13083-862 Campinas, SP, Brazil \\ Correspondence should be addressed to Ruann Janser Soares de Castro; ruannjanser@hotmail.com
}

Received 30 September 2014; Accepted 19 November 2014; Published 8 December 2014

Academic Editor: Harshadrai M. Rawel

Copyright (C) 2014 R. J. S. de Castro and H. H. Sato. This is an open access article distributed under the Creative Commons Attribution License, which permits unrestricted use, distribution, and reproduction in any medium, provided the original work is properly cited.

\begin{abstract}
This study reports the biochemical characterization of a protease from Aspergillus oryzae LBA 01 and the study of the antioxidant properties of protein hydrolysates produced with this protease. The biochemical characterization showed that the enzyme was most active over the $\mathrm{pH}$ range 5.0-5.5 and was stable from $\mathrm{pH} 4.5$ to 5.5 . The optimum temperature range for activity was $55-60^{\circ} \mathrm{C}$, and the enzyme was stable at temperatures below $45^{\circ} \mathrm{C}$. The activation energy $\left(E_{a}\right)$ for azocasein hydrolysis and temperature quotient $\left(Q_{10}\right)$ were found to be $37.98 \mathrm{~kJ} \mathrm{~mol}^{-1}$ and $1.64-1.53$ at temperature range from 30 to $55^{\circ} \mathrm{C}$, respectively. The enzyme exhibited $t_{1 / 2}$ of $97.63 \mathrm{~min}$ and a $D$ value of 324.31 at the optimum temperature for activity $\left(57.2^{\circ} \mathrm{C}\right)$. Protease from $A$. oryzae LBA 01 was shown as a potentially useful biocatalyst for protein hydrolysis, increasing the antioxidant activities of soy protein isolate, bovine whey protein, and egg white protein from 2.0- to 10.0-fold.
\end{abstract}

\section{Introduction}

Proteases are multifunctional enzymes and represent a fundamental group of enzymes due to diversity of their physiological roles and biotechnological applications [1]. These enzymes are extremely important in the pharmaceutical, medical, food, and biotechnology industries, accounting for nearly $60 \%$ of the whole enzyme market [2]. It has been estimated that microbial proteases represent approximately $40 \%$ of the total worldwide enzyme sales [3]. Fungi are a potential source of proteases due to their broad biochemical diversity, their susceptibility to genetic manipulation, high productivity, and being extracellular and are easily recoverable from the fermentation medium $[1,4]$.

Aspergillus oryzae (A. oryzae) is a filamentous fungus listed as a "Generally Recognized as Safe (GRAS)" organism by the US Food and Drug Administration. It has a long history of use in the food industry in the production of traditional fermented foods, due to its high proteolytic activity and its use of sugar [5, 6]. According to Machida et al.
[7] the molecular history of the organism shows that A. oryzae has the largest expansion of hydrolytic genes (135 proteinase genes).

The biochemical characterization of enzymes is important to evaluate their biotechnological potential. The study of the protease properties, such as the influence of inhibitors or activators, the substrate specificity, the optimum catalytic $\mathrm{pH}$ conditions and the temperature, and stability profiles and kinetic parameters, can be used to predict the successful application of the enzyme to particular industries or processes.

The application of proteases to the hydrolysis of animal and plant proteins to increase their biological and functional properties has attracted much attention. The antioxidant activities of protein hydrolysates are extensively reported in several studies. It is postulated that the antioxidant characteristics of peptides come from their abilities to inactivate reactive oxygen species (ROS), scavenge free radicals, chelate prooxidative transition metals, and reduce hydroperoxides [8]. Thus, studies of the application of new proteolytic enzyme 
sources are critical to advancing the knowledge concerning bioactive peptides.

In this context, the main objectives of the present study were to determine the biochemical characteristics of a protease from $A$. oryzae LBA 01 produced under solid state fermentation, including the optimum $\mathrm{pH}$ and temperature for activity and stability, the effects of ions and inhibitors on the protease activity and the kinetic parameters $K_{m}$ and $V_{\max }$, half-life, decimal reduction time, activation energy, and temperature quotient. After the biochemical characterization, the application of the protease to protein hydrolysis for the study of the antioxidant properties of the hydrolysates was evaluated.

\section{Materials and Methods}

2.1. Protease from Aspergillus oryzae LBA 01. A protease from A. oryzae LBA 01 (strain obtained from the culture collection of the Laboratory of Food Biochemistry, School of Food Engineering, University of Campinas, Brazil) was obtained by solid state fermentation using wheat bran as a substrate in $500 \mathrm{~mL}$ Erlenmeyer flasks containing $40 \mathrm{~g}$ of cultivation medium. The following predefined cultivation parameters were used: $50 \%$ initial moisture, $23^{\circ} \mathrm{C}$ inoculum of $10^{7}$ spores $\mathrm{g}^{-1}, 2 \%(\mathrm{w} / \mathrm{w})$ peptone, and $2 \%(\mathrm{w} / \mathrm{w})$ yeast extract. The crude extract was obtained after incubating for $72 \mathrm{~h}$, adding $150 \mathrm{~mL}$ of acetate buffer for $1 \mathrm{~h}$, and filtering following the final incubation. The crude extract was concentrated by ammonium sulfate $(80 \%)$ precipitation, dialysis, and freeze-drying. The partial purified preparation was used for biochemical characterization and protein hydrolysis experiments.

2.2. Determination of Protease Activities. The protease activity was measured using azocasein as the substrate according to Charney and Tomarelli [9] with slight modifications. The reaction mixture containing $0.5 \mathrm{~mL} 0.5 \%(\mathrm{w} / \mathrm{v})$ azocasein (Sigma-Aldrich, Steinheim, Germany), pH 5.0, and $0.5 \mathrm{~mL}$ of the enzyme solution was incubated for $40 \mathrm{~min}$. The reaction was stopped by adding $0.5 \mathrm{~mL} 10 \%$ TCA (trichloroacetic acid) and the test tubes were centrifuged at $17,000 \times \mathrm{g}$ for $15 \mathrm{~min}$ at $25^{\circ} \mathrm{C}$. A $1.0 \mathrm{~mL}$ aliquot of the supernatant was neutralized with $1.0 \mathrm{~mL} 5 \mathrm{M} \mathrm{KOH}$. One unit of enzyme activity (U) was defined as the amount of enzyme required to increase the absorbance at $428 \mathrm{~nm}$ by 0.01 under the assay conditions described.

The effect of the substrate concentration on the protease activity was also studied using casein and hemoglobin, as described below.

The protease activity using casein as the substrate was assayed as described by Chow and Peticolas [10] with modifications. The reaction mixture containing $2.5 \mathrm{~mL} 1.2 \%$ $(\mathrm{w} / \mathrm{v})$ casein, $\mathrm{pH} 6.0$, and $0.5 \mathrm{~mL}$ of the enzyme solution was incubated at $55^{\circ} \mathrm{C}$ for $10 \mathrm{~min}$. The reaction was stopped by adding $2.5 \mathrm{~mL} 5.0 \%$ TCA, and the reaction mixture was incubated in an ice-bath for $20 \mathrm{~min}$. The reaction mixture was filtered through filter paper (Whatman number 1), and the absorbance of the filtrate was measured at $280 \mathrm{~nm}$. One unit of enzyme activity was defined as the amount of protease required to increase the absorbance at $280 \mathrm{~nm}$ by 0.01 under the assay conditions described.

The protease activity using hemoglobin as the substrate was determined according to the Food Chemical Codex [11]. The reaction mixture containing $5.0 \mathrm{~mL} 2.0 \%(\mathrm{w} / \mathrm{v})$ hemoglobin, $\mathrm{pH} 4.7$, and $1.0 \mathrm{~mL}$ of the enzyme solution was incubated for $30 \mathrm{~min}$ at $55^{\circ} \mathrm{C}$. The reaction was stopped by adding $5.0 \mathrm{~mL} \mathrm{15 \%} \mathrm{TCA}$; the reaction mixture was left to stand for $1 \mathrm{~h}$, and it was filtered and its absorbance was measured at $275 \mathrm{~nm}$. One unit of enzyme activity was defined as the amount of protease required to increase the absorbance at $275 \mathrm{~nm}$ by 0.01 under the assay conditions described.

\subsection{Effects of pH and Temperature on the Activity and Stability} of the Protease Determined Using an Experimental Design. The optimum $\mathrm{pH}$ and temperature for activity and stability were determined using a central composite rotatable design (CCRD) with three replicates at the central point and four axial points (a total of 11 runs). The coded and real values of these variables are given in Table 1. To study the protease stability, the enzyme was incubated for $1 \mathrm{~h}$ at various $\mathrm{pH}$ values and temperatures.

The experiments were randomized to maximize the variability in the observed responses caused by extraneous factors. A second-order model equation was used for this model, represented by the following equation:

$$
Y=\beta_{0}+\sum_{i=1}^{n} \beta_{i} x_{i}+\sum_{i=1}^{n-1} \sum_{j=i+1}^{n} \beta_{i j} x_{i} x_{j},
$$

where $Y$ is the estimated response, $i$ and $j$ equal values from 1 to the number of variables $(n), \beta_{0}$ is the intercept term, $\beta_{i}$ values are the linear coefficients, $\beta_{i j}$ values are the quadratic coefficients, and $x_{i}$ and $x_{j}$ are the coded independent variables. The coefficient of determination $R^{2}$ and the $F$ test (analysis of variance (ANOVA)) were used to verify the quality of the fit of the second-order model equation. The Statistica 10.0 software from Statsoft Inc. (Tulsa, Oklahoma, USA) was employed for experimental design, data analysis, and model building.

2.4. Determination of Kinetic Parameters: Thermal Inactivation, Activation Energy, Temperature Quotient $\left(Q_{10}\right)$, and $K_{m}$ and $V_{\max }$ of the Semipurified Protease. The protease stability as a function of the time was evaluated. For this, the enzyme was incubated for $300 \mathrm{~min}$ at the optimal conditions of $\mathrm{pH}$ and temperature for activity, previously determined, and the samples were collected at various times for determination of the residual protease activity. The value of the deactivation rate constant $\left(k_{d}\right)$ for the protease at the optimal temperature for activity, expressed as an exponential decay, was found by plotting $\ln \left(A / A_{0}\right)$ versus time using the experimental data as shown in the following equation:

$$
A=A_{0} \times e^{-k_{d} t}
$$

where $t$ is time, $A_{0}$ is the initial enzyme activity, and $A$ is the enzyme activity at a determined time $t$. 
TABLE 1: The central composite rotatable design (CCRD) matrix used to determine the optimum $\mathrm{pH}$ and temperature for activity and stability of the protease from A. oryzae LBA 01, with the coded and real values for the variables and responses.

\begin{tabular}{|c|c|c|c|}
\hline \multicolumn{4}{|c|}{ Optimum $\mathrm{pH}$ and temperature for protease activity } \\
\hline \multirow{2}{*}{ Runs } & \multicolumn{2}{|c|}{ Independent variables } & \multirow{2}{*}{ Protease activity $\left(\mathrm{U} \cdot \mathrm{g}^{-1}\right)$} \\
\hline & $x_{1} / \mathrm{pH}$ & $x_{2} /$ temperature $\left({ }^{\circ} \mathrm{C}\right)$ & \\
\hline 1 & $-1(5.3)$ & $-1(39.4)$ & $2,151.34 \pm 1.88$ \\
\hline 2 & $+1(6.7)$ & $-1(39.4)$ & $921.91 \pm 17.83$ \\
\hline 3 & $-1(5.3)$ & $+1(60.6)$ & $3,961.30 \pm 132.97$ \\
\hline 4 & $+1(6.7)$ & $+1(60.6)$ & $957.53 \pm 1.88$ \\
\hline 5 & $-1.41(5.0)$ & $0(50.0)$ & $2,703.55 \pm 2.50$ \\
\hline 6 & $+1.41(7.0)$ & $0(50.0)$ & $880.76 \pm 18.46$ \\
\hline 7 & $0(6.0)$ & $-1.41(35.0)$ & $1,361.51 \pm 61.32$ \\
\hline 8 & $0(6.0)$ & $+1.41(65.0)$ & $1,691.60 \pm 91.36$ \\
\hline 9 & $0(6.0)$ & $0(50.0)$ & $2,863.29 \pm 0.63$ \\
\hline 10 & $0(6.0)$ & $0(50.0)$ & $2,878.33 \pm 30.04$ \\
\hline 11 & $0(6.0)$ & $0(50.0)$ & $2,989.39 \pm 31.29$ \\
\hline \multicolumn{4}{|c|}{ Optimum $\mathrm{pH}$ and temperature for protease stability } \\
\hline Runs & $x_{1} / \mathrm{pH}$ & $x_{2} /$ temperature $\left({ }^{\circ} \mathrm{C}\right)$ & Relative activity (\%) \\
\hline 1 & $-1(4.4)$ & $-1(39.4)$ & $91.50 \pm 3.07$ \\
\hline 2 & $+1(6.6)$ & $-1(39.4)$ & $71.94 \pm 3.84$ \\
\hline 3 & $-1(4.4)$ & $+1(60.6)$ & $39.79 \pm 4.97$ \\
\hline 4 & $+1(6.6)$ & $+1(60.6)$ & $0.32 \pm 0.10$ \\
\hline 5 & $-1.41(4.0)$ & $0(50.0)$ & $57.71 \pm 3.63$ \\
\hline 6 & $+1.41(7.0)$ & $0(50.0)$ & $17.98 \pm 3.30$ \\
\hline 7 & $0(5.5)$ & $-1.41(35.0)$ & $100.00 \pm 5.35$ \\
\hline 8 & $0(5.5)$ & $+1.41(65.0)$ & $0.59 \pm 0.17$ \\
\hline 9 & $0(5.5)$ & $0(50.0)$ & $80.37 \pm 2.80$ \\
\hline 10 & $0(5.5)$ & $0(50.0)$ & $80.47 \pm 3.46$ \\
\hline 11 & $0(5.5)$ & $0(50.0)$ & $80.38 \pm 3.92$ \\
\hline
\end{tabular}

The apparent half-life of the enzyme, defined as the time where the residual activity reaches $50 \%$, was estimated as shown in the following equation:

$$
t_{1 / 2}=\frac{\ln (0.5)}{k_{d}}
$$

Decimal reduction time ( $D$ value) was defined as the time required for a one- $\log _{10}$ reduction or $90 \%$ reduction in the initial enzyme activity at a specific temperature. The $D$ value is related to the first-order deactivation rate constant $\left(k_{d}\right)$ and it was calculated as shown in the following equation:

$$
D=\frac{2.303}{k_{d}} .
$$

The activation energy $\left(E_{a}\right)$ was determined by incubating the protease with $0.5 \%$ azocasein at various temperatures ranging from 30 to $80^{\circ} \mathrm{C}$ in $50 \mathrm{mM}$ acetate buffer ( $\mathrm{pH}$ 5.1). The dependence of the rate constants with temperature was assumed to follow the Arrhenius Law and $E_{a}$ was calculated from the slope of the plot of $1000 / T$ versus $\ln$ protease activity, where $E_{a}=$-slope $\times R, R$ (gas constant) = $8.314 \mathrm{~J} \mathrm{~K}^{-1} \mathrm{~mol}^{-1}$, and $T$ is the absolute temperature $[12,13]$.

The effect of temperature on the rate of reaction was expressed in terms of temperature quotient $\left(Q_{10}\right)$, which is the factor by which the rate increases due to a rise in the temperature by $10^{\circ} \mathrm{C} \cdot Q_{10}$ was calculated by the equation given by Dixon and Webb [14], as shown in

$$
Q_{10}=\operatorname{antilog}_{\varepsilon}\left(E_{a} \times \frac{10}{R T^{2}}\right) .
$$

Casein, azocasein, and hemoglobin were used over the concentration ranges 4.0-20.0, 1.0-10.0, and 2.0$20.0 \mathrm{mg} \cdot \mathrm{mL}^{-1}$, respectively, to determine the kinetic parameters $K_{m}$ and $V_{\max }$ of the protease from A. oryzae LBA 01 . The Michaelis-Menten constant $\left(K_{m}\right)$ and maximum velocity $\left(V_{\max }\right)$ values were determined as the reciprocal absolute values of the intercepts on the $x$ - and $y$-axes, respectively, of the linear regression curve. The $K_{m}$ value for a given enzyme provides an indication of the binding strength of that enzyme to its substrate; thus, a low $K_{m}$ indicates a higher affinity for the substrate. The $V_{\max }$ can be defined as the maximum velocity as the total amount of enzyme participates in the reaction [15]. The measurements were made at the optimum temperature as previously determined.

2.5. Effects of Ions and Inhibitors on the Protease Activity. The effects of metal ions and inhibitors on the enzyme activity 
were evaluated by the preincubation of the enzyme with different concentrations $(0.05,0.5$, and $5.0 \mathrm{mM})$ of various salts and inhibitors for $1 \mathrm{~h}$ at room temperature. The residual protease activity was assayed using azocasein as the substrate at optimum conditions. Each experiment was performed in triplicate.

2.6. Application of the Protease to Protein Hydrolysis. The soy protein isolate (SPI), bovine whey protein (BWP), and egg white protein (EWP) used as the substrates for enzymatic hydrolysis were kindly provided by Bunge Foods S/A (Gaspar, Brazil), Alibra Ingredients Ltd. (Campinas, Brazil), and Cooperovos (Mogi das Cruzes, Brazil), respectively. The protease from $A$. oryzae LBA 01 was used for enzymatic hydrolysis. The enzyme concentrations were adjusted to 0 (control), 20, or $40 \mathrm{U}$ per $\mathrm{mL}$ of reaction mixture. The proteins were suspended in acetate buffer to a final concentration of $100 \mathrm{mg} \cdot \mathrm{mL}^{-1}$, and $50 \mathrm{~mL}$ aliquots of the mixtures were distributed in $125 \mathrm{~mL}$ Erlenmeyer flasks. Hydrolysis was performed at the optimum temperature and $\mathrm{pH}$ value of the enzyme for $240 \mathrm{~min}$. After hydrolysis, the samples were incubated in a water bath at $100^{\circ} \mathrm{C}$ for $20 \mathrm{~min}$ for protease inactivation. The mixtures were centrifuged at $17,000 \times \mathrm{g}$ at $5^{\circ} \mathrm{C}$ for $20 \mathrm{~min}$, and the supernatants containing the peptides were collected and freeze-dried for the determination of their antioxidant activities.

\subsection{Determination of Antioxidant Activities}

2.7.1. ORAC Assay. The ORAC method used herein, with fluorescein (FL) as the "fluorescent probe," was developed by Dávalos et al. [16]. The automated ORAC assay was performed on a NovoStar Microplate reader (BMG LABTECH, Ortenberg, Germany) with fluorescence filters for an excitation wavelength of $485 \mathrm{~nm}$ and an emission wavelength of $520 \mathrm{~nm}$. The measurements were made in a COSTAR 96-well plate. The reaction was performed at $37^{\circ} \mathrm{C}$; the reaction was initiated by the thermal decomposition of AAPH (2,2'-azobis(2-methylpropionamidine) dihydrochloride) (Sigma-Aldrich, Steinheim, Germany) in a $75 \mathrm{mM}$ phosphate buffer (PBS, pH 7.4) due to the sensitivity of FL to $\mathrm{pH}$. The solution of $\mathrm{FL}\left(0.4 \mu \mathrm{g} \cdot \mathrm{mL}^{-1}\right)$ in PBS (75 mM, pH 7.4) was prepared daily and stored in complete darkness. The reference standard was a $75 \mu \mathrm{M}$ Trolox (( \pm )-6-hydroxy-2,5,7,8-tetramethylchroman-2-carboxylic acid) (Sigma-Aldrich, Steinheim, Germany) solution, prepared daily in distilled water and diluted to 1500$1.5 \mu \mathrm{mol} \cdot \mathrm{L}^{-1}$ to prepare the Trolox standard curve. In each well, $120 \mu \mathrm{L}$ of the FL solution was mixed with either $20 \mu \mathrm{L}$ sample, blank (distilled water), or standard (Trolox solutions) before $60 \mu \mathrm{L}$ AAPH $\left(108 \mathrm{mg} \cdot \mathrm{mL}^{-1}\right)$ was added. The fluorescence was measured immediately after the addition of AAPH, and measurements were then taken every $1 \mathrm{~min}$ for $75 \mathrm{~min}$. The measurements were taken in triplicate. The ORAC values were calculated using the difference between the area under the FL decay curve and the blank (net AUC). The regression equations between the net AUC and the antioxidant concentration were calculated for all samples. The ORAC values were expressed as $\mu \mathrm{mol}$ of Trolox equivalent. $\mathrm{g}^{-1}$ of protein hydrolysates (Trolox EQ $\mu \mathrm{mol} \cdot \mathrm{g}^{-1}$ ).

2.7.2. DPPH Radical-Scavenging Activity. The DPPH (2,2diphenyl-1-picrylhydrazyl) (Sigma-Aldrich, Steinheim, Germany) radical-scavenging activity of the hydrolysates was determined as described by Bougatef et al. [17]. A $500 \mu \mathrm{L}$ aliquot of the protein hydrolysates $\left(5 \mathrm{mg} \cdot \mathrm{mL}^{-1}\right)$ was mixed with $500 \mu \mathrm{L} 99.5 \%$ ethanol and $125 \mu \mathrm{L} 0.02 \% \mathrm{DPPH}$ in $99.5 \%$ ethanol. The mixture was then kept at room temperature in the dark for $60 \mathrm{~min}$, and the reduction of the DPPH radical was measured at $517 \mathrm{~nm}$ using a UV-visible spectrophotometer (Beckman DU 70 spectrophotometer, Beckman-Coulter, Inc., Fullerton, CA, USA). The DPPH radical-scavenging activity was calculated as follows:

Radical scavenging activity (\%)

$=\left[\frac{\text { Absorbance of control }- \text { Absorbance of sample }}{\text { Absorbance of control }}\right] * 100$.

The control reaction was performed in the same manner, except that distilled water was used instead of sample. Trolox was used as a standard. The tests were performed in triplicate. The results of the tests were expressed as $\mu \mathrm{mol}$ of Trolox equivalent. $\mathrm{g}^{-1}$ of protein hydrolysates (Trolox EQ $\mu \mathrm{mol} \cdot \mathrm{g}^{-1}$ ) and DPPH radical scavenging (\%).

2.8. Calculations and Statistics. Values are expressed as the arithmetic mean. The Tukey test was used to check the significant differences between the groups analyzed. The differences were considered significant when $P<0.05$.

\section{Results and Discussion}

3.1. Effects of $p H$ and Temperature on the Activity and Stability of the Protease Determined Using an Experimental Design. The partially purified preparation was biochemically characterized. Table 1 shows the CCRD with its independent variables ( $\mathrm{pH}$ and temperature) and the results for protease activity and stability.

The highest value obtained for the protease activity was observed in run $3\left(3,961.30 \mathrm{U} \cdot \mathrm{g}^{-1}\right)$, and the lowest was $880.76 \mathrm{U} \cdot \mathrm{g}^{-1}$ detected in run 6 . For protease stability, the highest value was observed when the enzyme was incubated at $35.0^{\circ} \mathrm{C} \mathrm{pH} 5.5$ (run 7). The protease demonstrated lower stability at temperatures above $50.0^{\circ} \mathrm{C}$ and $\mathrm{pH}$ range 6.0 7.0, reaching residual activities of 0.32 (run 4) and $0.59 \%$ (run 8). The limited variability of the central points (runs 911) indicated good reproducibility of the experimental data (Table 1).

Table 2 showed the models, $R^{2}, F$-values, probability values for the final reduced models, and the validation tests performed under the conditions predicted by the models of the $\mathrm{pH}$ and temperature for optimum activity and stability of the protease from A. oryzae LBA 01. For protease activity, the linear, quadratic terms for the $\mathrm{pH}\left(x_{1}\right)$ and temperature 
TABLE 2: Models, $R^{2}, F$ test, probability values, and validation tests for the final reduced models of the $\mathrm{pH}$ and temperature for optimum activity and stability of the proteases from A. oryzae LBA 01.

\begin{tabular}{|c|c|c|c|c|c|c|}
\hline \multicolumn{7}{|c|}{ Optimum $\mathrm{pH}$ and temperature for the protease activity } \\
\hline Responses & \multicolumn{2}{|c|}{ Equations } & $F$ test & $F$ tabulated & $R^{2}$ & $P$ value \\
\hline Protease activity $\left(\mathrm{U} \cdot \mathrm{g}^{-1}\right)$ & \multicolumn{2}{|c|}{$Y=-57,219.4+13,285.9 \mathrm{pH}-958.8 \mathrm{pH}^{2}+928.7 T-5.4 T^{2}-59.8 \mathrm{pH} \times T$} & 12.1 & 3.45 & 0.92 & $<0.01$ \\
\hline \multicolumn{7}{|c|}{$\mathrm{pH}$ and temperature for the protease stability } \\
\hline Relative activity (\%) & \multicolumn{2}{|c|}{$Y=-489.4+172.5 \mathrm{pH}-16.9 \mathrm{pH}^{2}+8.4 T-0.1 T^{2}$} & 70.8 & 3.18 & 0.98 & $<0.01$ \\
\hline \multicolumn{7}{|c|}{ Validation tests } \\
\hline \multicolumn{2}{|c|}{ Maximum protease activity } & Predicted response $\left(\mathrm{U} \cdot \mathrm{g}^{-1}\right)$ & \multicolumn{4}{|c|}{ Experimental response $\left(\mathrm{U} \cdot \mathrm{g}^{-1}\right)$} \\
\hline \multicolumn{2}{|c|}{ Protease activity $\left(\mathrm{U} \cdot \mathrm{g}^{-1}\right)$ pH $5.1 \quad$ Temperature $57.2^{\circ} \mathrm{C}$} & $3,528.01$ & \multicolumn{4}{|c|}{$3,411.49 \pm 549.81$} \\
\hline \multicolumn{2}{|c|}{ Maximum protease stability } & Predicted response & \multicolumn{4}{|c|}{ Experimental response } \\
\hline Relative activity (\%) & pH 5.1 Temperature $36.5^{\circ} \mathrm{C}$ & $\geq 95.0 \% / \geq 3,559.28 \mathrm{U} \cdot \mathrm{g}^{-1}$ & \multicolumn{4}{|c|}{$97.23 \% / 3,460.62 \pm 34.35$} \\
\hline
\end{tabular}

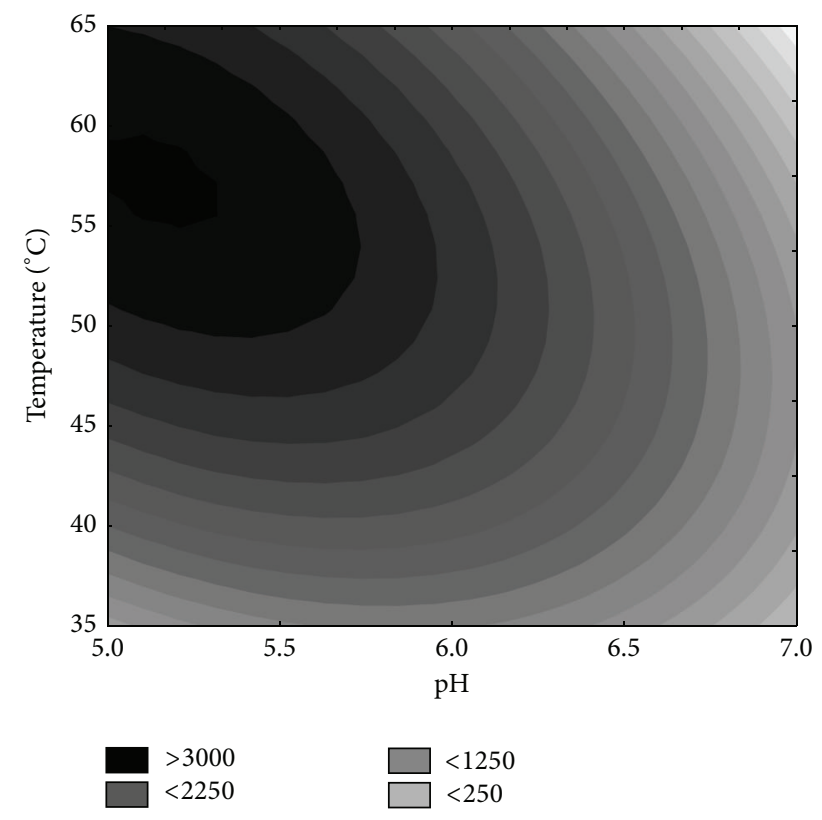

(a)

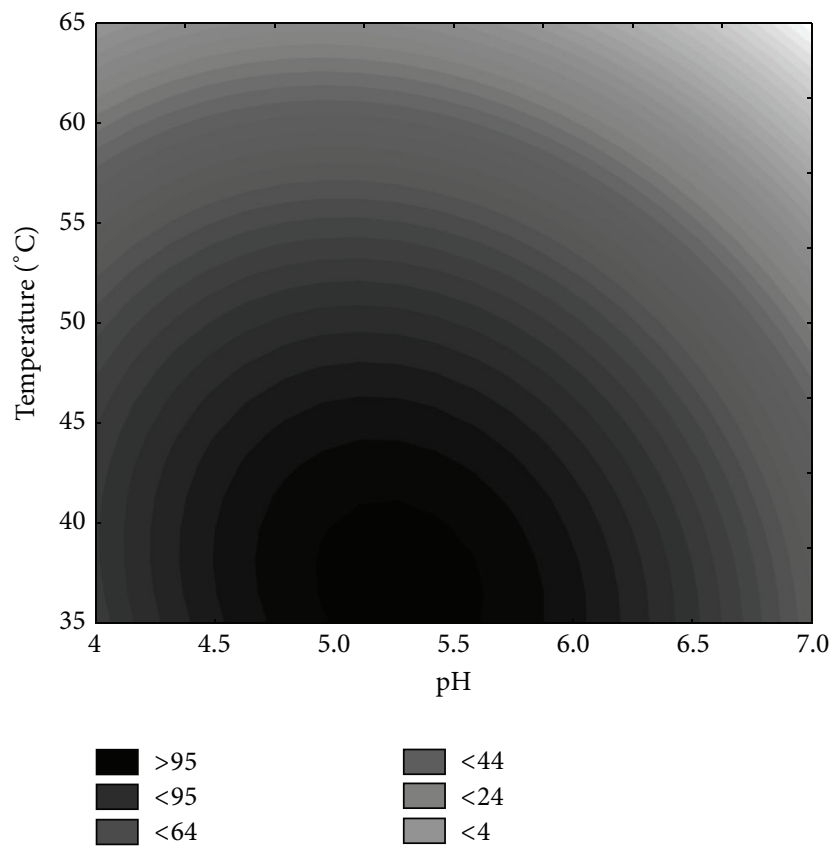

(b)

FIGURE 1: Contour plots for the protease activity $\left(\mathrm{U} \cdot \mathrm{g}^{-1}\right)$ and stability (\% residual activity) as a function of the pH and the temperature $\left({ }^{\circ} \mathrm{C}\right)$.

$\left(x_{2}\right)$ as well as the interaction $\mathrm{pH} x$ temperature $\left(x_{1} x_{2}\right)$ demonstrated a significant effect $(P<0.05)$ (Table 2). The linear terms of $\mathrm{pH}\left(x_{1}\right)$ and temperature $\left(x_{2}\right)$ showed positive effects on the protease stability, while the quadratic terms indicated negative effects. These results showed that the increasing $\mathrm{pH}$ and temperature positively influenced the stability of proteases, but from a certain value, this effect started to be negative and quadratic. The interaction term $(\mathrm{pH} \times T)$ was not statistically significant for protease stability (Table 2).

An analysis of variance (ANOVA) showed that $92-98 \%$ of the total variation was explained by the models. All $F$-values tested for the regressions were greater than the tabulated $F$ values $(P$ value $<0.01)$, reflecting the statistical significance of the model equations (Table 2 ).

The contour plots were generated from the models. The protease from $A$. oryzae LBA 01 was more active in the $\mathrm{pH}$ range $5.0-5.5$ and the temperature range $55-60^{\circ} \mathrm{C}$. The protease activity increased as the temperature increased. In contrast, the $\mathrm{pH}$ had a negative effect, with lower protease activity in the neutral region (Figure 1(a)). For protease stability, the contour plot showed that the acid protease was more stable in the $\mathrm{pH}$ range 4.5-5.5 and in the temperature range $35-45^{\circ} \mathrm{C}$ after $1 \mathrm{~h}$ (Figure $1(\mathrm{~b})$ ). The protease produced by $A$. oryzae LBA 01 demonstrated $\mathrm{pH}$ and temperature activity profiles similar to those of the acid proteases from Rhizopus oryzae, which showed optimum activity at $\mathrm{pH} 5.5$ and $60.0^{\circ} \mathrm{C}$, and from A. oryzae MTCC 5341, which showed more activity in the $\mathrm{pH}$ range $3.0-4.0$ at $55.0^{\circ} \mathrm{C}[1,18]$. A protease from $A$. niger ATCC 11414 exhibited maximum activity at $\mathrm{pH} 4.0$ and $50.0^{\circ} \mathrm{C}$ and it was stable in a wide $\mathrm{pH}$ range (2.2-10.0) and at temperatures lower than $70.0^{\circ} \mathrm{C}$ [19]. Silva et al. [1] showed that an acid protease from $A$. clavatus was more active at $\mathrm{pH} 5.5$ and $50.0^{\circ} \mathrm{C}$ and its high stability in 


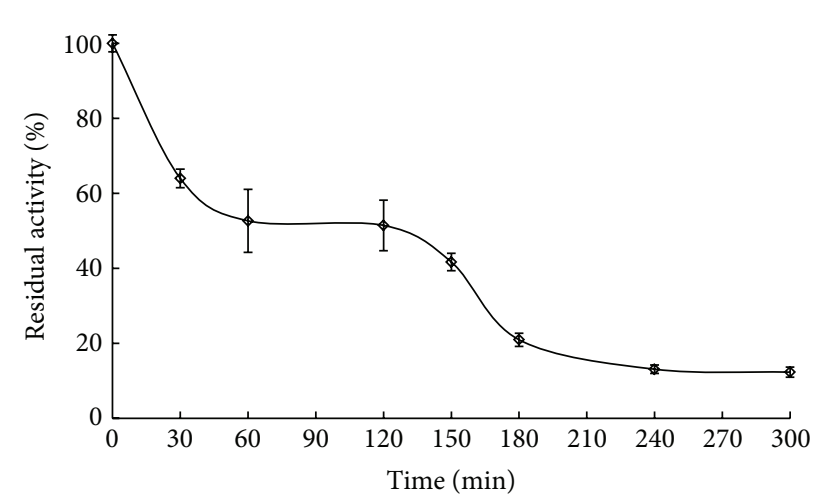

(a)

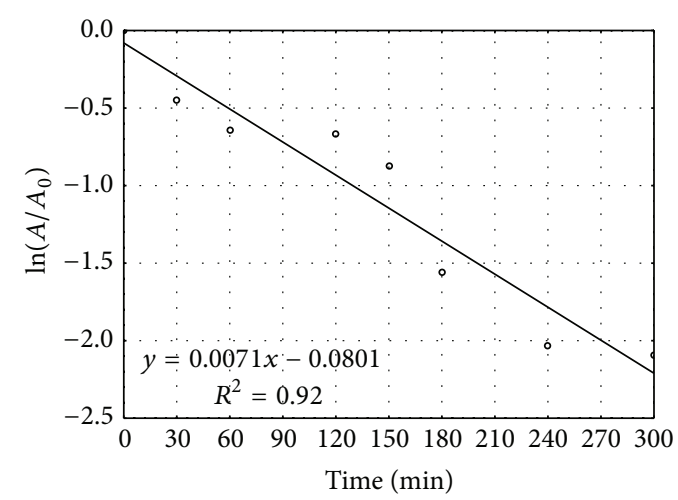

(b)

FIgURE 2: Residual activity of the protease from A. oryzae LBA 01 incubated for $300 \mathrm{~min}$ at optimum $\mathrm{pH}$ and temperature for activity (a) and Arrhenius plot for thermal inactivation (b).

the $\mathrm{pH}$ range of 3.5-6.5. In general, fungal acid proteases are stable between $\mathrm{pH} 2.5$ and 6.0 [4].

Validation tests were performed to determine the accuracy of the polynomial models obtained for the protease activity and stability with three assays (Table 2). The optimum conditions for protease activity and stability determined according to the CCRD analysis were $\mathrm{pH} 5.1$ and $57.2^{\circ} \mathrm{C}$ and $\mathrm{pH} 5.1$ and $36.5^{\circ} \mathrm{C}$, respectively. The Tukey test showed that the experimental values agreed with the values predicted by the models within a $95.0 \%$ confidence interval, thereby confirming the validity of the models for the evaluated responses (Table 2).

3.2. Determination of Kinetic Parameters: Thermal Inactivation, Activation Energy, Temperature Quotient $\left(Q_{10}\right)$, and $K_{m}$ and $V_{\max }$ of the Semipurified Protease. In order to determine the protease stability at the optimum conditions for enzyme activity, the protease from A. oryzae LBA 01 was incubated at $\mathrm{pH} 5.1$ and $57.2^{\circ} \mathrm{C}$ for $300 \mathrm{~min}$. The results showed that the enzyme retained about $50.0 \%$ of its activity after $120 \mathrm{~min}$ of incubation, showing a decrease of more than $80.0 \%$ in protease activity after $180 \mathrm{~min}$ of incubation (Figure 2(a)). Figure 2(b) describes the Arrhenius plot used to calculate the various kinetic $\left(k_{d}, t_{1 / 2}\right.$, and $\left.D\right)$ parameters for thermal inactivation study of the protease from A. oryzae LBA 01 at the optimum temperature for activity $\left(57.2^{\circ} \mathrm{C}\right)$. The half-life $\left(t_{1 / 2}\right)$ of an enzyme, at a given temperature, is the time it takes for the activity to reduce to a half of its original/initial activity. The decimal reduction time ( $D$ value) is defined as the time required for a $90 \%$ reduction in the initial enzyme activity. Higher $t_{1 / 2}$ and $D$ values at the specific operating temperature are important and desirable parameters for industrial applications since they indicate the resistance of the enzyme to thermal inactivation. The protease exhibited $k_{d}$ value of $0.007 \mathrm{~min}^{-1}, t_{1 / 2}$ of $97.63 \mathrm{~min}$, and a $D$ value of 324.31 at $57.2^{\circ} \mathrm{C}$ (Table 3).

Several studies reported a lower stability of proteases at temperatures around $50.0-60.0^{\circ} \mathrm{C}$. García-Gómez et al. [20] performed a comparative study between a protease produced by A. oryzae 2095 by solid state fermentation and a commercial protease (Flavourzyme $500 \mathrm{MG}$ ). The enzymes were subjected to a thermic treatment at $50.0^{\circ} \mathrm{C}$ for $2 \mathrm{~h}$; the residual activity was $22.0 \%$ for the protease from A. oryzae 2095, while Flavourzyme 500 MG was almost inactivated. A neutral protease produced by Aspergillus oryzae CICIM F0899 was kinetically characterized and the results showed half-lives $\left(t_{1 / 2}\right)$ of 20.4 and $14.2 \mathrm{~min}$ at 55.0 and $60.0^{\circ} \mathrm{C}$, respectively [21]. Sant'Anna et al. [22] studied the kinetic modeling of thermal inactivation of a protease from Bacillus sp. and showed $D$ values of $432.54,131.41,17.98$, and $7.82 \mathrm{~min}$ at $45,50,55$, and $65^{\circ} \mathrm{C}$, respectively.

The activation energy of the protease was calculated at temperatures between 30 and $80^{\circ} \mathrm{C}$ (Figure 3 ). The Arrhenius plots in temperature range from 30 to $55^{\circ} \mathrm{C}$ showed a linear variation with temperature increase, suggesting that the protease from A. oryzae LBA 01 has a single conformation up to the transition temperature (Figure 3(a)).

$E_{a}$ presented a positive value $\left(37.98 \mathrm{~kJ} \mathrm{~mol}^{-1}\right)$ in the temperature range from 30.0 to $55.0^{\circ} \mathrm{C}$ (Figure 3(b)) and a negative value $\left(-94.87 \mathrm{~kJ} \mathrm{~mol}^{-1}\right)$ in the temperature range from 55.0 to $80.0^{\circ} \mathrm{C}$ (Figure 3(c)), indicating that catalysis reactions suppress enzymatic deactivation below the inflection point (Table 3). Melikoglu et al. [23] reported similar results for a protease from Aspergillus awamori, which presented activation energies $\left(E_{a}\right)$ for bread protein hydrolysis of $36.8 \mathrm{~kJ} \mathrm{~mol}^{-1}$ in the temperature range from 30.0 to $55.0^{\circ} \mathrm{C}$ and $-62.0 \mathrm{~kJ} \mathrm{~mol}^{-1}$ in the temperature range from 55.0 to $65.0^{\circ} \mathrm{C}$.

The effect of temperature on rate of reaction was measured in terms of temperature quotient $\left(Q_{10}\right)$. The $Q_{10}$ value of the protease from A. oryzae LBA 01 was estimated in 1.641.53 at temperatures ranging from 30 to $55^{\circ} \mathrm{C}$ (Table 3).

Enzyme kinetics was performed by means of the model of Lineweaver-Burk and the parameters $K_{m}$ and $V_{\max }$ were determined using azocasein, casein, and hemoglobin as substrates. The protease from A. oryzae LBA 01 demonstrated the greatest affinity for the substrate hemoglobin, with $K_{m}$ and $V_{\max }$ values estimated at $0.7 \mathrm{mg} \cdot \mathrm{mL}^{-1}$ and 
TABLE 3: Kinetic parameters for the protease from A. oryzae LBA 01 produced under solid state fermentation of wheat bran.

\begin{tabular}{|c|c|c|c|}
\hline \multicolumn{4}{|c|}{ Kinetic activation parameters } \\
\hline Temperature range $\left({ }^{\circ} \mathrm{C}\right)$ & $E_{a}\left(\mathrm{~kJ} \mathrm{moL}^{-1}\right)$ & $R^{2}$ & $Q_{10}$ \\
\hline $30-55$ & 37.98 & 0.99 & $1.64-1.53$ \\
\hline $55-80$ & -94.87 & 0.95 & \\
\hline \multicolumn{4}{|c|}{ Michaelis-Menten constant $\left(K_{m}\right)$ and maximum rate for the enzymatic reaction $\left(V_{\max }\right)$} \\
\hline Substrate & $K_{m}\left(\mathrm{mg} \cdot \mathrm{mL}^{-1}\right)$ & & \\
\hline Casein & 4.9 & & \\
\hline Azocasein & 2.5 & & \\
\hline Hemoglobin & 0.7 & & \\
\hline \multicolumn{4}{|c|}{ Kinetic parameters for irreversible thermal denaturation } \\
\hline Temperature $\left({ }^{\circ} \mathrm{C}\right)$ & $k_{d}\left(\min ^{-1}\right) \quad t_{1 / 2}(\min )$ & $D(\min )$ & $R^{2}$ \\
\hline 57.2 & 0.0071 & 324.31 & 0.92 \\
\hline
\end{tabular}

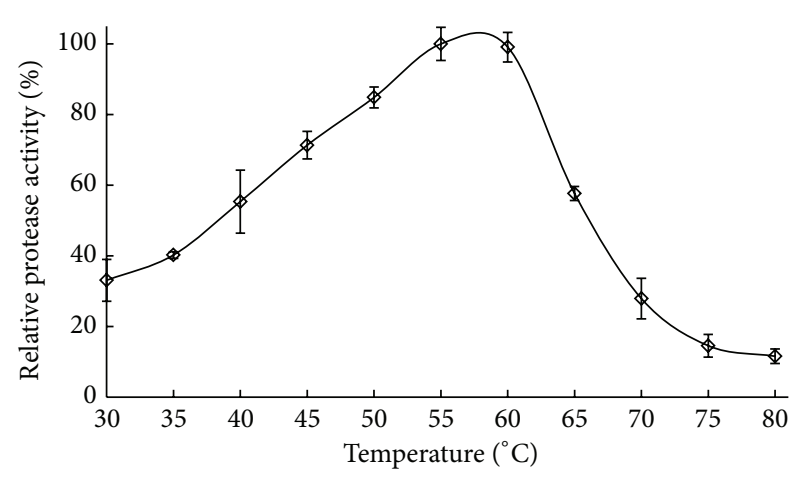

(a)

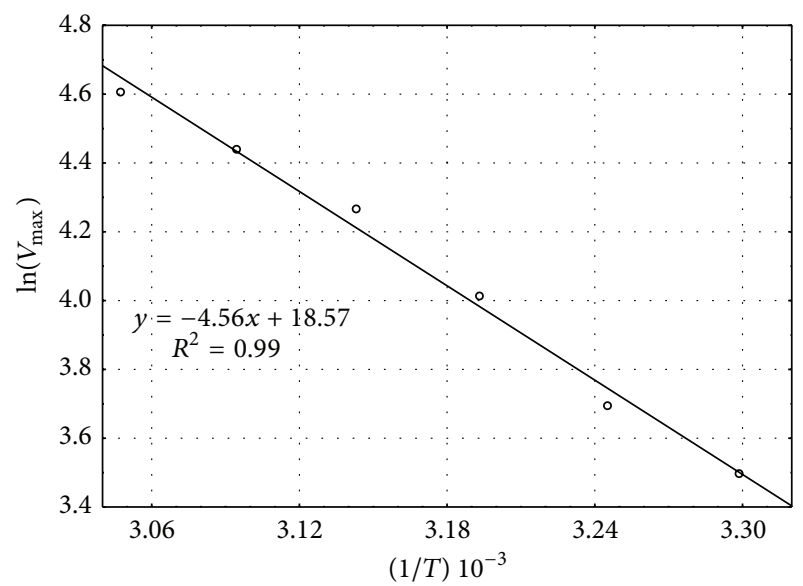

(b)

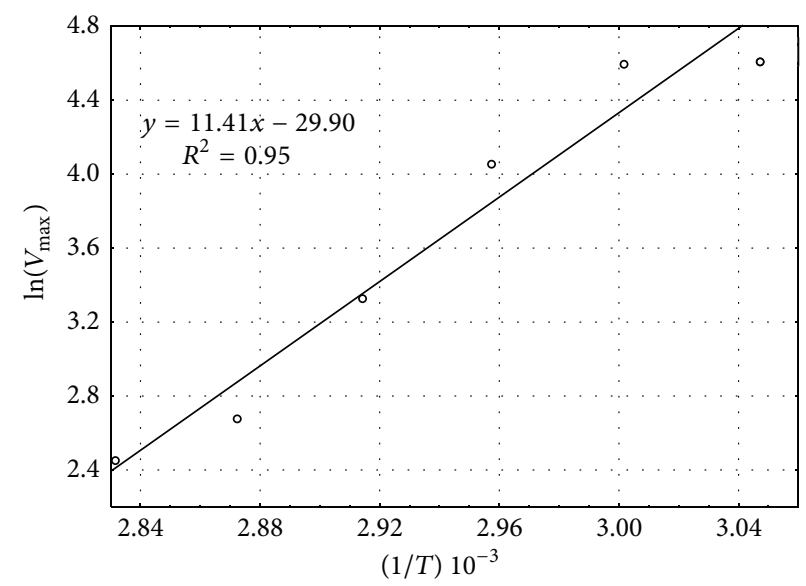

(c)

FIGURE 3: The effects of temperature on the protease activity (a) and Arrhenius plots to calculate activation energy $\left(E_{a}\right)$ in temperature range from 30 to $55^{\circ} \mathrm{C}$ (b) and from 55 to $80^{\circ} \mathrm{C}$ (c) of protease from A. oryzae LBA 01.

$2,764 \mathrm{U} \cdot \mathrm{g}^{-1}$, respectively. The $K_{m}$ and $V_{\max }$ values of the protease for the substrates casein and azocasein were estimated at $4.9 \mathrm{mg} \cdot \mathrm{mL}^{-1}$ and $5446.3 \mathrm{U} \cdot \mathrm{g}^{-1}$ and $2.5 \mathrm{mg} \cdot \mathrm{mL}^{-1}$ and $5139.3 \mathrm{U} \cdot \mathrm{g}^{-1}$, respectively (Table 3 ).
3.3. Effects of Various Salts and Compounds on the Protease Activity. The effect of some monovalent and divalent cations and other compounds on the enzymatic activity is summarized in Table 4 . None of the ions tested increased the protease 
TABlE 4: The effects of various salts and compounds on the protease activity.

\begin{tabular}{|c|c|c|c|}
\hline \multirow{3}{*}{$\begin{array}{l}\text { Ions and inhibitors } \\
\text { Control }\end{array}$} & \multicolumn{3}{|c|}{ Residual activity (\%) } \\
\hline & $0.05 \mathrm{mM}$ & $0.5 \mathrm{mM}$ & $5.0 \mathrm{mM}$ \\
\hline & \multicolumn{3}{|c|}{$100.00 \pm 4.57$} \\
\hline $\mathrm{ZnSO}_{4}$ & $96.59 \pm 7.63$ & $55.41 \pm 3.82$ & $23.88 \pm 2.44$ \\
\hline $\mathrm{MgSO}_{4}$ & $97.10 \pm 4.13$ & $97.77 \pm 4.10$ & $97.21 \pm 2.12$ \\
\hline $\mathrm{FeSO}_{4}$ & $90.45 \pm 5.09$ & $42.96 \pm 3.44$ & Undetected \\
\hline $\mathrm{MnSO}_{4}$ & $105.99 \pm 4.63$ & $89.56 \pm 4.67$ & $80.87 \pm 5.89$ \\
\hline $\mathrm{CaCl}_{2}$ & $95.03 \pm 5.11$ & $92.73 \pm 5.31$ & $93.96 \pm 1.56$ \\
\hline $\mathrm{CuSO}_{4}$ & $82.68 \pm 2.83$ & $22.19 \pm 0.61$ & $13.98 \pm 3.53$ \\
\hline $\mathrm{NaCl}$ & $99.39 \pm 2.22$ & $103.13 \pm 2.01$ & $100.29 \pm 4.49$ \\
\hline $\mathrm{CoCl}_{2}$ & $88.71 \pm 0.67$ & $72.72 \pm 4.51$ & Undetected \\
\hline$\left(\mathrm{NH}_{4}\right)_{2} \mathrm{SO}_{4}$ & $100.66 \pm 4.08$ & $98.52 \pm 3.34$ & $95.73 \pm 3.00$ \\
\hline Glutathione & $97.95 \pm 3.97$ & $97.29 \pm 3.22$ & $101.97 \pm 3.36$ \\
\hline Cysteine & $98.26 \pm 3.96$ & $87.23 \pm 2.76$ & $46.80 \pm 2.29$ \\
\hline $\mathrm{KCl}$ & $96.55 \pm 4.93$ & $91.62 \pm 4.46$ & $30.65 \pm 4.77$ \\
\hline $\mathrm{Mg}\left(\mathrm{NO}_{3}\right)_{2}$ & $98.01 \pm 0.46$ & $97.38 \pm 3.16$ & $94.31 \pm 1.72$ \\
\hline $\mathrm{MnCl}_{2}$ & $101.74 \pm 3.93$ & $92.17 \pm 8.80$ & $73.83 \pm 7.17$ \\
\hline $\mathrm{CaCO}_{3}$ & $101.65 \pm 3.41$ & $96.99 \pm 1.36$ & $52.01 \pm 2.75$ \\
\hline EDTA & $101.52 \pm 2.02$ & $100.13 \pm 3.47$ & $99.25 \pm 3.56$ \\
\hline Iodoacetamide & $79.98 \pm 3.87$ & $63.79 \pm 2.51$ & $33.20 \pm 3.10$ \\
\hline p-Chloromercuribenzoate & $98.89 \pm 4.55$ & $97.52 \pm 2.86$ & $94.66 \pm 2.47$ \\
\hline Sodium azide & $96.03 \pm 0.26$ & $97.20 \pm 1.55$ & $97.38 \pm 5.20$ \\
\hline N-Bromosuccinimide & $78.56 \pm 3.76$ & $10.56 \pm 2.12$ & $5.10 \pm 1.40$ \\
\hline Urea & $96.73 \pm 2.99$ & $94.70 \pm 3.43$ & $92.58 \pm 3.20$ \\
\hline
\end{tabular}

Results are presented as the mean $(n=3) \pm \mathrm{SD}$ (standard deviation).

activity, but a strong inhibition was verified in the presence of some ions. The protease from A. oryzae LBA 01 retained more than $92 \%$ of its initial activity in the presence of the compounds $\mathrm{MgSO}_{4}, \mathrm{CaCl}_{2}, \mathrm{NaCl},\left(\mathrm{NH}_{4}\right)_{2} \mathrm{SO}_{4}$, glutathione, $\mathrm{Mg}\left(\mathrm{NO}_{3}\right)_{2}$, EDTA, p-chloromercuribenzoate, sodium azide, and urea at concentrations from 0.05 to $5.0 \mathrm{mM}$. The addition of $5 \mathrm{mM} \mathrm{FeSO}_{4}$ and $\mathrm{CoCl}_{2}$ completely inhibited the protease activity. The addition of $5 \mathrm{mM} \mathrm{ZnSO}_{4}, \mathrm{CuSO}_{4}, \mathrm{KCl}, \mathrm{CaCO}_{3}$, cysteine, iodoacetamide, and N-bromosuccinimide inhibited the protease with residual activities of $23.88 \%, 13.98 \%$, $52.01 \%, 46.80 \%, 33.20 \%$, and 5.10\%, respectively (Table 4). The enzyme was not inhibited by the addition of EDTA, indicating that metal ions are not necessary for the activity of the protease from A. oryzae LBA 01. Matsushita-Morita et al. [6] reported that a protease from A. oryzae ATCC 42149 was activated in the presence of the metal ions $\mathrm{Zn}^{2+}$ and $\mathrm{Co}^{2+}$ at final concentrations of $1 \mathrm{mM}$. In the same study, the addition of $1 \mathrm{mM} \mathrm{Ca}^{2+}, \mathrm{Mg}^{2+}$, or $\mathrm{Mn}^{2+}$ inhibited the enzyme.

3.4. Antioxidant Activities of Protein Hydrolysates. The antioxidant activity of the hydrolysates was evaluated using ORAC and DPPH assays. The ORAC assay has been broadly applied in academics and the food and supplement industry as a method of choice to quantify antioxidant capacity [24]. ORAC measures antioxidant inhibition of peroxyl radical induced oxidations and thus reflects classical radical chain breaking antioxidant activity by $\mathrm{H}$ atom transfer. In the basic assay, the peroxyl radical reacts with a fluorescent probe to form a nonfluorescent product, which can be quantitated easily by fluorescence [25]. In the study of the protease application to protein hydrolysis, the results showed that the antioxidant activity of the proteins increased after their enzymatic hydrolysis. For the ORAC assay, the enzymatic hydrolysis of SPI, WHEY, and EGG by the protease from $A$. oryzae LBA 01 resulted in maximal antioxidant activity values of $645.20 \pm 104.78,172.11 \pm 17.32$, and $469.65 \pm 47.80$ Trolox EQ $\mu \mathrm{mol} \cdot \mathrm{g}^{-1}$, respectively (Table 5 ). The best results were observed when $40 \mathrm{U}$ protease per $\mathrm{mL}$ of reaction mixture was added to the protein solution. The antioxidant activity of the EGG hydrolysates prepared with the protease from $A$. oryzae LBA 01 increased the most compared with the control (Table 5).

A standard assay is essential for comparing the results of different studies. In several studies, research groups used different methodologies to determine the antioxidant activity of protein hydrolysates, which may result in differences in the concentrations of radicals, incubation times, reaction solvents, $\mathrm{pH}$, and temperatures of the reaction mixtures. In addition, the inherent variables of the process, including substrate, enzyme, $\mathrm{pH}$, temperature, and hydrolysis time, can produce many types of hydrolysates, each with different antioxidant properties. The experimental data variability complicates the comparisons among different studies.

Tavares et al. [26] investigated the antioxidant activity of bovine whey protein hydrolyzed by cardosins. The antioxidant activity of the whey hydrolysates was $0.96 \pm$ $0.08 \mu \mathrm{mol}$ Trolox EQ per mg hydrolyzed protein (ORAC 
TABLE 5: Antioxidant activities from the DPPH and ORAC assays and linearity ranges for the ORAC assay (net AUC versus concentration) performed on the control and hydrolysate samples produced by the protease from A. oryzae LBA 01 .

\begin{tabular}{|c|c|c|c|c|c|c|c|c|}
\hline \multirow[b]{2}{*}{$\begin{array}{l}\text { Protein } \\
\text { source }\end{array}$} & \multirow[b]{2}{*}{$\begin{array}{l}\text { Protease } \\
\left(\mathrm{U} \cdot \mathrm{mL}^{-1}\right)\end{array}$} & \multicolumn{2}{|c|}{$\mathrm{DPPH}$} & \multicolumn{5}{|c|}{ ORAC } \\
\hline & & $\begin{array}{l}\text { Trolox EQ } \\
\mu \mathrm{mol} \cdot \mathrm{g}^{-1}\end{array}$ & $\begin{array}{c}\text { Radical } \\
\text { scavenging (\%) }\end{array}$ & $\begin{array}{l}\text { Trolox EQ } \\
\mu \mathrm{mol} \cdot \mathrm{g}^{-1}\end{array}$ & $\begin{array}{l}\text { Sample concentration } \\
\text { range }\left(\mathrm{mg} \cdot \mathrm{mL}^{-1}\right)\end{array}$ & Slope & Intercept & $R^{2}$ \\
\hline \multirow{3}{*}{ SPI } & Control & $0.88 \pm 0.14^{\mathrm{a}}$ & $30.77 \pm 1.53^{\mathrm{a}}$ & $186.11 \pm 48.45^{\mathrm{a}}$ & $0.25-1.00$ & 0.11 & -0.07 & 0.94 \\
\hline & 20 & $4.61 \pm 0.12^{\mathrm{b}}$ & $69.18 \pm 1.54^{\mathrm{b}}$ & $574.35 \pm 46.15^{\mathrm{b}}$ & $0.25-1.00$ & 0.04 & -0.08 & 0.99 \\
\hline & 40 & $4.25 \pm 0.08^{c}$ & $66.43 \pm 0.95^{\mathrm{c}}$ & $645.20 \pm 104.78^{\mathrm{b}}$ & $0.30-1.20$ & 0.04 & -0.22 & 0.99 \\
\hline \multirow{3}{*}{ WHEY } & Control & $2.44 \pm 0.11^{\mathrm{a}}$ & $40.67 \pm 0.28^{\mathrm{a}}$ & $18.51 \pm 7.20^{\mathrm{a}}$ & $1.15-4.60$ & 0.61 & 0.25 & 0.99 \\
\hline & 20 & $4.92 \pm 0.09^{\mathrm{b}}$ & $73.62 \pm 0.07^{\mathrm{b}}$ & $132.61 \pm 6.43^{\mathrm{b}}$ & $1.00-4.00$ & 0.14 & -0.15 & 0.99 \\
\hline & 40 & $4.53 \pm 0.01^{\mathrm{c}}$ & $69.53 \pm 0.07^{\mathrm{c}}$ & $172.11 \pm 17.32^{c}$ & $1.20-4.80$ & 0.13 & -0.59 & 0.99 \\
\hline \multirow{3}{*}{ EGG } & Control & $4.42 \pm 0.11^{\mathrm{a}}$ & $63.03 \pm 1.56^{\mathrm{a}}$ & $47.18 \pm 7.45^{\mathrm{a}}$ & $1.05-4.20$ & 0.34 & -0.04 & 0.99 \\
\hline & 20 & $1.89 \pm 0.30^{\mathrm{b}}$ & $45.93 \pm 3.17^{\mathrm{b}}$ & $423.43 \pm 56.80^{\mathrm{b}}$ & $0.50-2.00$ & 0.06 & -0.32 & 0.99 \\
\hline & 40 & Undetected & $33.99 \pm 1.41^{\mathrm{c}}$ & $469.65 \pm 47.80^{\mathrm{b}}$ & $0.50-2.00$ & 0.05 & -0.24 & 0.99 \\
\hline
\end{tabular}

$\overline{\mathrm{a}, \mathrm{b}, \mathrm{c}}$ Results are presented as the mean $(n=3) \pm \mathrm{SD}$, and those with different letters are significantly different, with $P<0.05$. Comparisons were made between the values of each protein source (not between different protein sources). The DPPH assay was carried out using sample concentration of $5 \mathrm{mg} \cdot \mathrm{mL}^{-1}$.

values). Contreras et al. [27] tested the antioxidant activity of the whey protein concentrate hydrolyzed using Corolase $\mathrm{PP}$ and thermolysin. The results showed that the higher enzyme:substrate ratio was best suited to produce the hydrolysates, resulting in antioxidant activity of 2.57 Trolox EQ $\mu \mathrm{mol}$ per mg protein (ORAC values). Bovine casein hydrolysates obtained by enzymatic hydrolysis with a Ficus carica L. latex proteinase were investigated for their antioxidant abilities using ORAC assay. The highest ORAC values were detected for the samples hydrolyzed during 138 and 240 min with 1.189 and $1.187 \mu \mathrm{mol}$ Trolox $\mathrm{mg}^{-1}$ of freeze-dried sample, respectively [28].

DPPH radical is a stable free radical that shows maximal absorbance at $517 \mathrm{~nm}$ in ethanol and has been widely used to test the ability of natural compounds to act as free radical scavengers or hydrogen donors, as a means for evaluating their antioxidant potentials. When DPPH radical encounters a proton donating substance such as an antioxidant, the radicals would be scavenged and the absorbance is reduced [29]. For the DPPH assay, the SPI and WHEY hydrolysates prepared with the protease from $A$. oryzae LBA 01 showed higher antioxidant activity, with values of $4.61 \pm 0.12$ and $4.92 \pm 0.09$ Trolox EQ $\mu \mathrm{mol} \cdot \mathrm{g}^{-1}$, respectively, compared with the EGG hydrolysates (Table 5). The greatest radical-scavenging activity $\left(73.62 \%\right.$ at $\left.5 \mathrm{mg} \cdot \mathrm{mL}^{-1}\right)$ was observed in the WHEY hydrolysates. For the SPI and WHEY hydrolysates, the use of $20 \mathrm{U}$ protease per $\mathrm{mL}$ of reaction mixture resulted in the maximum antioxidant activity. For the EGG hydrolysates, the hydrolysis had a negative effect, decreasing the antioxidant activity compared with the control (Table 5). The hydrolysis might be releasing the antioxidant peptides resulting in an increase in antioxidant activity of the hydrolysates, while other treatments might produce the peptides without antioxidant activities or hydrolyze the antioxidant peptides into amino acids and thus decrease the antioxidant activity of hydrolysate [30]. Zhang et al. [31] investigated the production of antioxidant hydrolysates from soy protein using three commercial microbial proteases: neutral protease from Bacillus subtilis, Validase from Aspergillus oryzae, and alkaline protease from Bacillus licheniformis. The maximum ORAC value observed was 83.8 Trolox EQ $\mu \mathrm{mol} \cdot \mathrm{g}^{-1}$, and the highest DPPH scavenging activity was $29.3 \%$ at $100 \mathrm{mg} \cdot \mathrm{mL}^{-1}$. Tanzadehpanah et al. [32] prepared egg white proteins hydrolysates using various proteases $(\alpha-$ chymotrypsin, pepsin, trypsin, and papain) and evaluated their antioxidant activities by DPPH radical-scavenging assay. In these studies, the protein hydrolysates prepared using trypsin exhibited the highest ability to scavenge DPPH radicals, reaching $77.0 \%$ DPPH radical scavenging at $200 \mu \mathrm{g}$ $\mathrm{mL}^{-1}$ after $6 \mathrm{~h}$ hydrolysis.

\section{Conclusion}

The results showed that the protease produced by A. oryzae LBA 01 was most active in the $\mathrm{pH}$ range 5.0-5.5 and stable from $\mathrm{pH} 4.5$ to 5.5 , indicative of an acid protease. The optimum temperature for activity was $55-60^{\circ} \mathrm{C}$, and the enzyme was stable at temperatures below $45^{\circ} \mathrm{C}$. Thermal studies indicated that the protease was thermally stable at optimum temperature for activity $\left(57.2^{\circ} \mathrm{C}\right)$, exhibiting $t_{1 / 2}$ of $97.63 \mathrm{~min}$ and a $D$ value of $324.31 \mathrm{~min}$. Activation energy $\left(E_{a}\right)$ for azocasein hydrolysis was $37.98 \mathrm{~kJ} \mathrm{moL}^{-1}$ and the temperature quotient $\left(Q_{10}\right)$ was 1.63-1.54 at temperature range from 30 to $55^{\circ} \mathrm{C}$. The protease was not inhibited by $5 \mathrm{mM}$ EDTA, indicating that metal ions were not necessary for enzyme activity. The protease from $A$. oryzae LBA 01 presented as an interesting biocatalyst for enzyme-based processes, especially for protein hydrolysis, increasing the natural antioxidant capacity of soy protein isolate, bovine whey protein, and egg white protein.

\section{Conflict of Interests}

The authors declare that there is no conflict of interests regarding the publication of this paper. 


\section{Acknowledgments}

The work described in this paper was substantially supported by grants from São Paulo Research Foundation (FAPESP) (Project no. 2011/10429-9) and the Department of Food Science, School of Food Engineering, University of Campinas, which are gratefully acknowledged. The authors acknowledge the National Counsel of Technological and Scientific Development $(\mathrm{CNPq})$ for the granting of scholarship.

\section{References}

[1] T. A. S. Silva, A. Knob, C. R. Tremacoldi, M. R. BrochettoBraga, and E. C. Carmona, "Purification and some properties of an extracellular acid protease from Aspergillus clavatus," World Journal of Microbiology and Biotechnology, vol. 27, no. 11, pp. 2491-2497, 2011.

[2] V. Ramakrishna, S. Rajasekhar, and L. S. Reddy, "Identification and purification of metalloprotease from dry grass pea (Lathyrus sativus L.) seeds," Applied Biochemistry and Biotechnology, vol. 160, no. 1, pp. 63-71, 2010.

[3] M. B. Rao, A. M. Tanksale, M. S. Ghatge, and V. V. Deshpande, "Molecular and biotechnological aspects of microbial proteases," Microbiology and Molecular Biology Reviews, vol. 62, no. 3, pp. 597-635, 1998.

[4] K. S. Vishwanatha, A. G. Appu Rao, and S. A. Singh, "Characterisation of acid protease expressed from Aspergillus oryzae MTCC 5341," Food Chemistry, vol. 114, no. 2, pp. 402-407, 2009.

[5] T. Gotou, T. Shinoda, S. Mizuno, and N. Yamamoto, "Purification and identification of proteolytic enzymes from Aspergillus oryzae capable of producing the antihypertensive peptide IlePro-Pro," Journal of Bioscience and Bioengineering, vol. 107, no. 6, pp. 615-619, 2009.

[6] M. Matsushita-Morita, S. Tada, S. Suzuki et al., "Overexpression and characterization of an extracellular Leucine Aminopeptidase from Aspergillus oryzae," Current Microbiology, vol. 62, no. 2, pp. 557-564, 2011.

[7] M. Machida, K. Asai, M. Sano et al., "Genome sequencing and analysis of Aspergillus oryzae," Nature, vol. 438, no. 7071, pp. 1157-1161, 2005.

[8] D. Y. Zhou, B. W. Zhu, L. Qiao et al., "In vitro antioxidant activity of enzymatic hydrolysates prepared from abalone (Haliotis discushannai Ino) viscera," Food and Bioproducts Processing, vol. 90, no. 2, pp. 148-154, 2012.

[9] J. Charney and R. M. Tomarelli, "A colorimetric method for the determination of the proteolytic activity of duodenal juice," The Journal of Biological Chemistry, vol. 171, pp. 501-505, 1947.

[10] B. F. Chow and M. A. Peticolas, "A rapid method for the determination of proteolytic activities of enzyme preparations," The Journal of General Physiology, vol. 32, no. 1, pp. 17-24, 1948.

[11] Food Chemical Codex, General Tests and Apparatus, Proteolytic Activity, Fungal (SAP), National Academy Press, Washington, DC, USA, 1981.

[12] K. S. Siddiqui, M. J. Azhar, M. H. Rashid, and M. I. Rajoka, "Activity and thermostability of carboxymethylcellulase from Aspergillus niger is strongly influenced by non-covalently attached polysaccharides," World Journal of Microbiology and Biotechnology, vol. 12, no. 3, pp. 213-216, 1996.

[13] A. Jakób, J. Bryjak, H. Wójtowicz, V. Illeová, J. Annus, and M. Polakovič, "Inactivation kinetics of food enzymes during ohmic heating," Food Chemistry, vol. 123, no. 2, pp. 369-376, 2010.
[14] M. Dixon and E. C. Webb, Enzymes, Academic Press, New York, NY, USA, 1979.

[15] H. Lineweaver and D. Burk, "The determination of enzyme dissociation constants," Journal of the American Chemical Society, vol. 56, no. 3, pp. 658-666, 1934.

[16] A. Dávalos, C. Gómez-Cordovés, and B. Bartolomé, “Extending applicability of the oxygen radical absorbance capacity (ORACfluorescein) assay," Journal of Agricultural and Food Chemistry, vol. 52, no. 1, pp. 48-54, 2004.

[17] A. Bougatef, M. Hajji, R. Balti, I. Lassoued, Y. Triki-Ellouz, and M. Nasri, "Antioxidant and free radical-scavenging activities of smooth hound (Mustelus mustelus) muscle protein hydrolysates obtained by gastrointestinal proteases," Food Chemistry, vol. 114, no. 4, pp. 1198-1205, 2009.

[18] S. Kumar, N. S. Sharma, M. R. Saharan, and R. Singh, "Extracellular acid protease from Rhizopus oryzae: purification and characterization," Process Biochemistry, vol. 40, no. 5, pp. 17011705, 2005.

[19] Y. Esparza, A. Huaiquil, L. Neira et al., "Optimization of process conditions for the production of a prolylendopeptidase by Aspergillus niger ATCC 11414 in solid state fermentation," Food Science and Biotechnology, vol. 20, no. 5, pp. 1323-1330, 2011.

[20] M. J. García-Gómez, S. Huerta-Ochoa, O. Loera-Corral, and L. A. Prado-Barragán, "Advantages of a proteolytic extract by Aspergillus oryzae from fish flour over a commercial proteolytic preparation," Food Chemistry, vol. 112, no. 3, pp. 604-608, 2009.

[21] D. Wang, Z.-Y. Zheng, J. Feng et al., "Influence of sodium chloride on thermal denaturation of a high-salt-tolerant neutral protease from Aspergillus oryzae," Food Science and Biotechnology, vol. 22, no. 5, pp. 1-7, 2013.

[22] V. Sant'Anna, A. P. F. Corrêa, D. J. Daroit, and A. Brandelli, "Kinetic modeling of thermal inactivation of the Bacillus sp. protease P7," Bioprocess and Biosystems Engineering, vol. 36, no. 7, pp. 993-998, 2013.

[23] M. Melikoglu, C. S. K. Lin, and C. Webb, "Kinetic studies on the multi-enzyme solution produced via solid state fermentation of waste bread by Aspergillus awamori," Biochemical Engineering Journal, vol. 80, pp. 76-82, 2013.

[24] D. Huang, B. Ou, and R. L. Prior, "The chemistry behind antioxidant capacity assays," Journal of Agricultural and Food Chemistry, vol. 53, no. 6, pp. 1841-1856, 2005.

[25] R. L. Prior, X. Wu, and K. Schaich, "Standardized methods for the determination of antioxidant capacity and phenolics in foods and dietary supplements," Journal of Agricultural and Food Chemistry, vol. 53, no. 10, pp. 4290-4302, 2005.

[26] T. G. Tavares, M. M. Contreras, M. Amorim et al., "Optimisation, by response surface methodology, of degree of hydrolysis and antioxidant and ACE-inhibitory activities of whey protein hydrolysates obtained with cardoon extract," International Dairy Journal, vol. 21, no. 12, pp. 926-933, 2011.

[27] M. D. M. Contreras, B. Hernández-Ledesma, L. Amigo, P. J. Martín-Álvarez, and I. Recio, "Production of antioxidant hydrolyzates from a whey protein concentrate with thermolysin: optimization by response surface methodology," $L W T$ : Food Science and Technology, vol. 44, no. 1, pp. 9-15, 2011.

[28] G. Di Pierro, M. B. O’Keeffe, A. Poyarkov, G. Lomolino, and R. J. Fitzgerald, "Antioxidant activity of bovine casein hydrolysates produced by Ficus carica L.-derived proteinase," Food Chemistry, vol. 156, pp. 305-311, 2014.

[29] P. Yang, H. Ke, P. Hong, S. Zeng, and W. Cao, "Antioxidant activity of bigeye tuna (Thunnus obesus) head protein hydrolysate 
prepared with Alcalase," International Journal of Food Science and Technology, vol. 46, no. 12, pp. 2460-2466, 2011.

[30] Y. Zhuang and L. Sun, "Preparation of reactive oxygen scavenging peptides from tilapia (Oreochromis niloticus) skin gelatin: optimization using response surface methodology," Journal of Food Science, vol. 76, no. 3, pp. 483-489, 2011.

[31] L. Zhang, J. Li, and K. Zhou, "Chelating and radical scavenging activities of soy protein hydrolysates prepared from microbial proteases and their effect on meat lipid peroxidation," Bioresource Technology, vol. 101, no. 7, pp. 2084-2089, 2010.

[32] H. Tanzadehpanah, A. Asoodeh, and J. Chamani, "An antioxidant peptide derived from Ostrich (Struthio camelus) egg white protein hydrolysates," Food Research International, vol. 49, no. 1, pp. 105-111, 2012. 

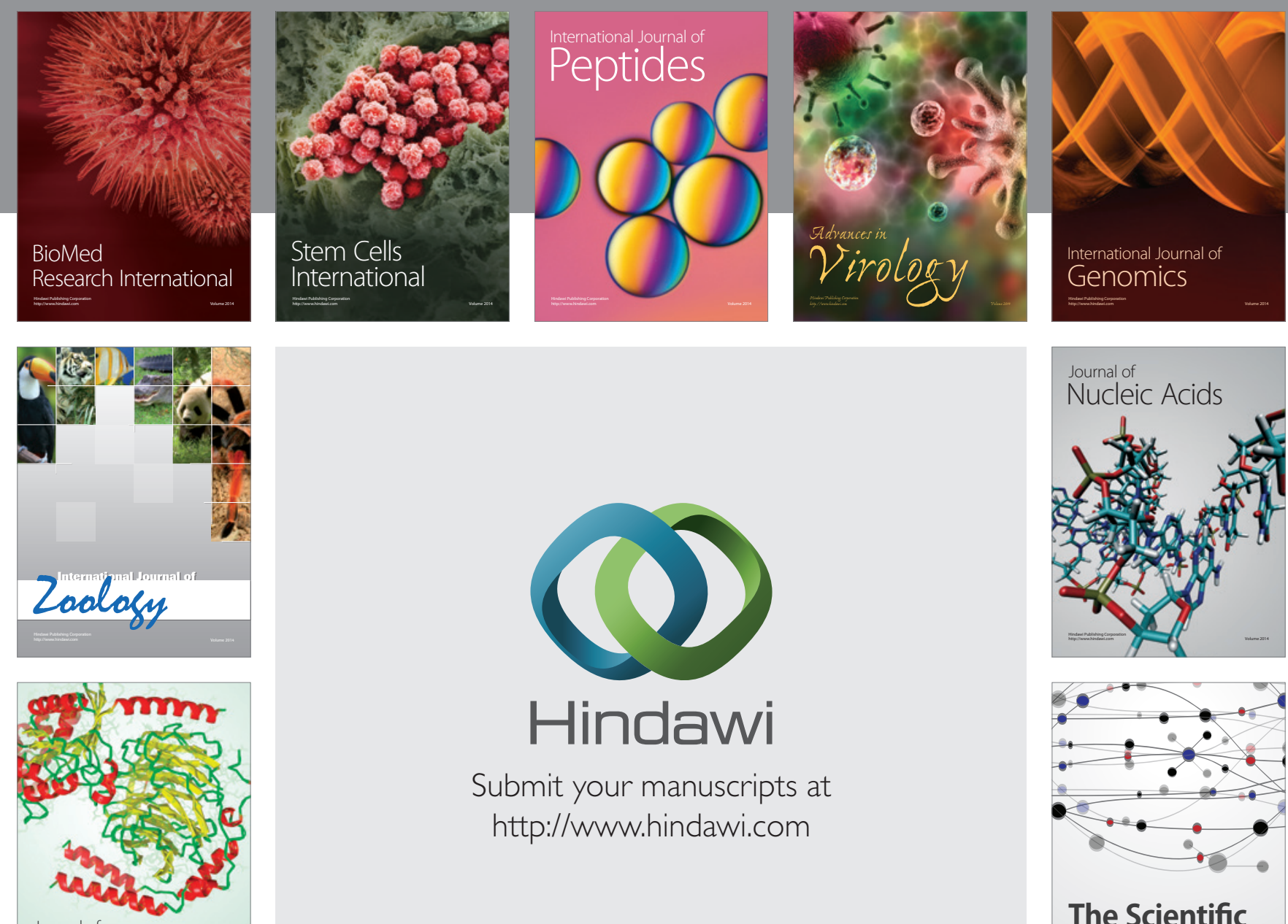

Submit your manuscripts at

http://www.hindawi.com

Journal of
Signal Transduction
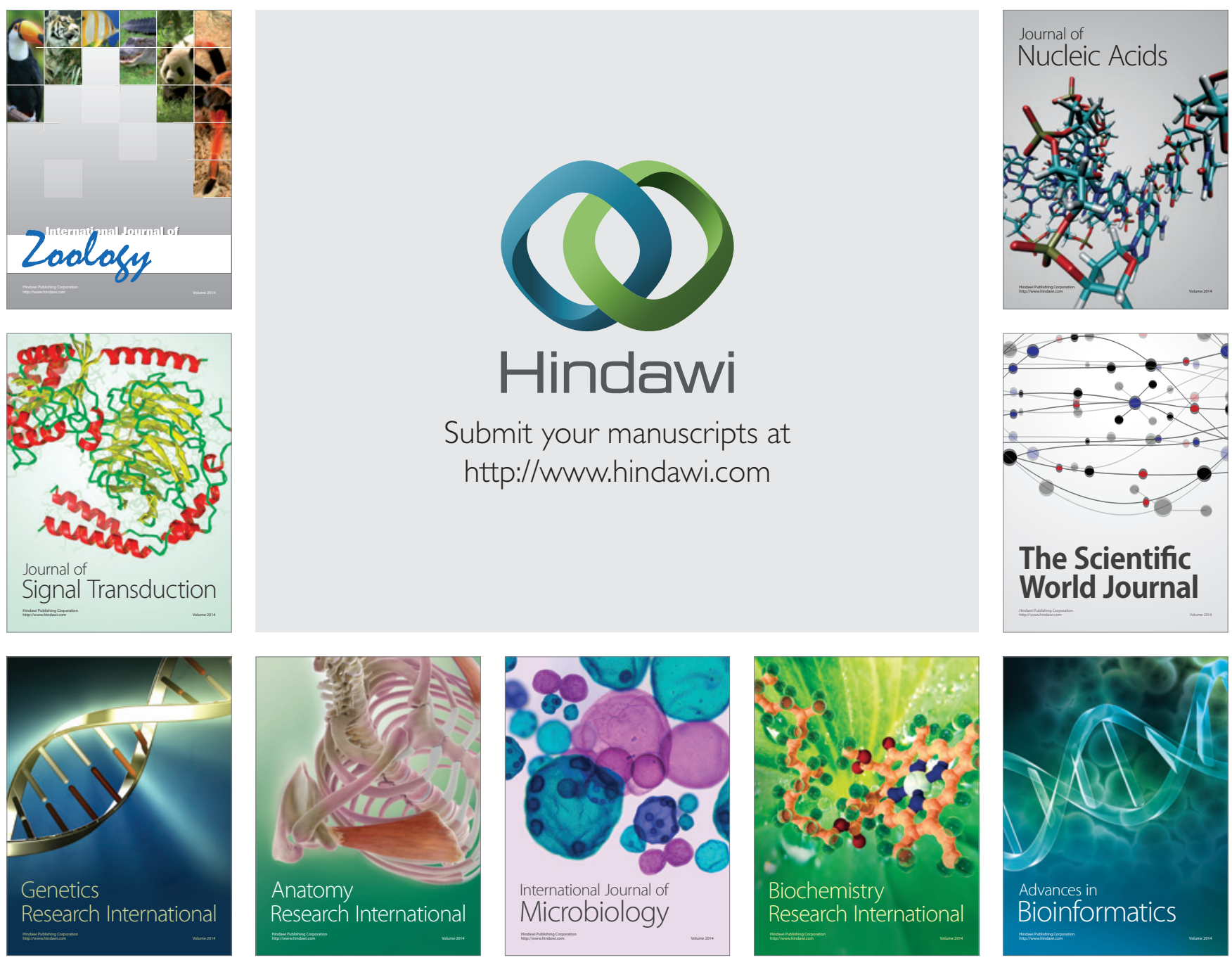

The Scientific World Journal
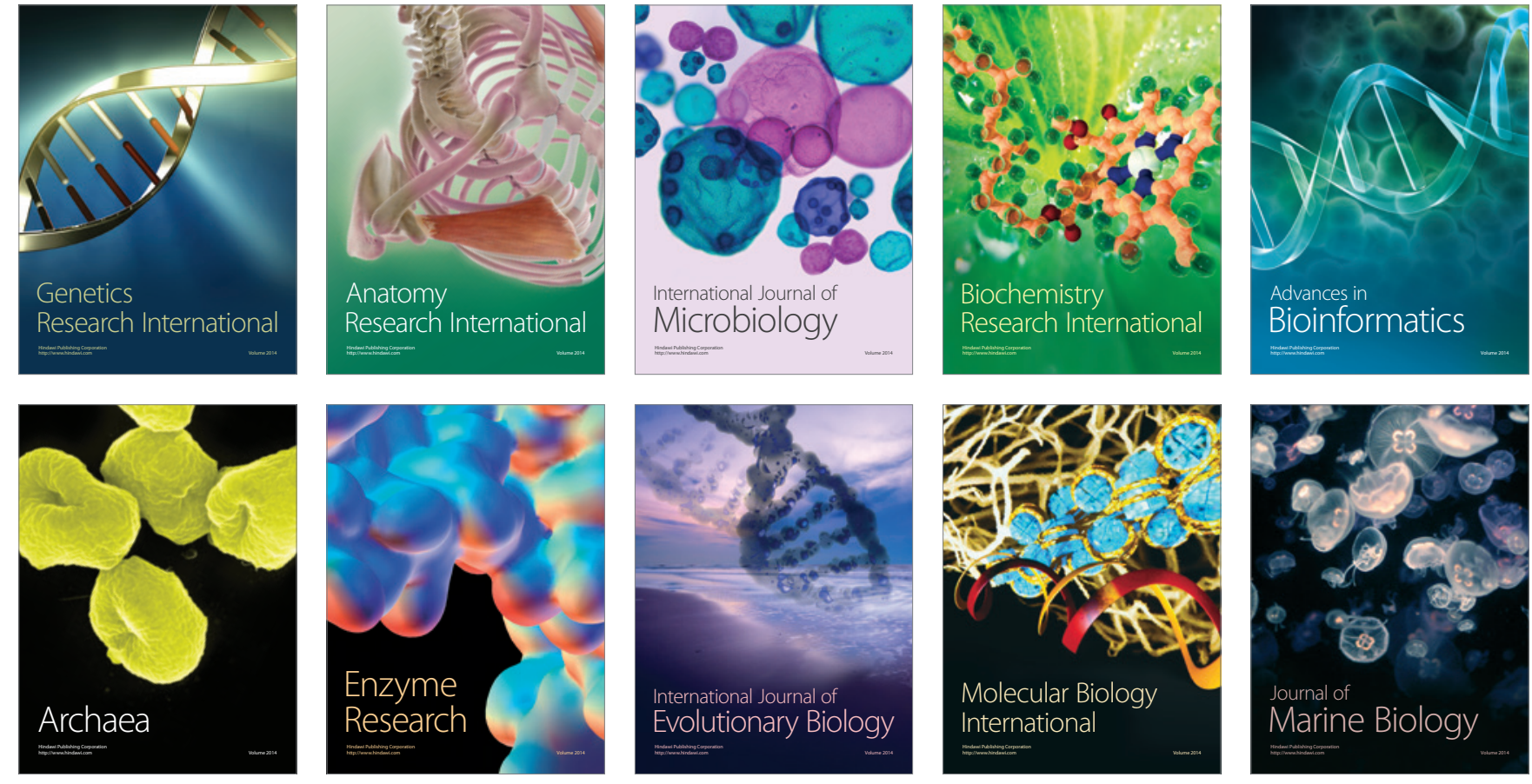